\title{
Respiratory Viral Infections in the Elderly in a Nursing Home
}

\author{
Masahiro YAMAKOSHI ${ }^{1)}$, Kanzou SUZUKI ${ }^{1)}$, Takasi NAKAKITA ${ }^{2)}$ \\ Noriko GOTO ${ }^{2)}$, Atsushi NAKAMURA ${ }^{3)}$ \& Yasuo YAMADA ${ }^{3)}$ \\ ${ }^{1)}$ Nagoyashi-Koseiin Geriatric Hospital \\ ${ }^{2)}$ Nagoya City Public Health Research Institute \\ ${ }^{3)}$ First Department of Internal Medicine, Nagoya City University Medical School \\ (Received: February 18, 1998) \\ (Accepted: May 26, 1998) \\ Key words: nursing home, respiratory viral infection
}

\begin{abstract}
The purpose of this study was to investigate what viruses infiltrate into our nursing home, assess the related clinical symptoms in elderly subjects, and compare the incidences of infections with those in the general community. Between July 1994 and June 1995, 40 elderly persons dwelling in the nursing home were evaluated by clinical observation, serologic analysis, and viral culture of samples to determine the presence of viruses. Enteroviruses and herpes simplex I virus could be isolated from asymptomatic elderly subjects. Individuals with influenza B virus and RSV infections diagnosed by serology did have clinical symptoms. The prevalence of both influenza B virus and enteroviruses was related to that of such viruses in the general community. Our data suggest that respiratory viruses are readily transmitted from the community to nursing home residents.
\end{abstract}

\section{Introduction}

Acute respiratory tract infections (ARTI) constitute the most common complaint of people of any age seeking medical attention. The frequency of respiratory infections is high in young children and appears to decline with advancing age ${ }^{1)}$. However, excess mortality related to influenza is found in broadly defined high-risk groups, one being composed of people over 65 years of age. More than $80 \%$ of the deaths attributed to pneumonia or influenza involve people 65 years of age or over ${ }^{2,3)}$. The respiratory syncytical virus (RSV), a major cause of lower respiratory infection in young children, is also a cause of serious infection in the elderly with associated high rates of pneumonia and mortality in nursing homes ${ }^{4,5}$. Our first objective in the present study was to ascertain what viruses infiltrate our nursing home and to assess the related clinical symptoms in elderly subjects. Our second objective was to compare the incidence of respiratory infection in the nursing home with that in the community. Outbreaks of viral infections in hospitals often mirror those in the community ${ }^{6}$, and our aim was to determine whether this is also the case for nursing homes.

\section{Materials and Methods}

\section{Subjects}

The subjects of this study were 40 elderly residents on the fourth floor of the nursing home next to Koseiin Geriatric Hospital, most of whom required intermediate-care. The 40 subjects were 11

Correspondence to : Masahiro YAMAKOSHI, M.D.

Department of Respiratory Disease, Kasugai Municipal Hospital, 2-43-1 Hata-cho, Kasugai-city, 486-8510, Aichi, Japan 
males and 29 females ranging in age from 66 to 99 years (mean 83.3 years), 4 (10\%) being bedridden. None of the subjects had received influenza vaccinations. The staff comprises 2 physicians, 3 nurses, and 15 assistants.

\section{Study design}

We explained our obsjectives to each participant, who gave his or her informed consent. Surveillance was conducted between July 1, 1994 and June 30, 1995. Viral cultures of nasopharyngeal samples were performed every 2 months in the latter part of the month. At the same time points, serum samples were collected for determination of viral antibody titers. In addition, staff members observed all residents with ARTI for general constitutional symptoms during the study period and made notes in their medical records, as well as providing information to attending doctors.

\section{Viral culture}

Specimens for isolation were collected from the nasopharynx with a cotton swab, placed in viral transport medium (Hanks' BBS $+0.5 \%$ lactalbumin hydrolysate), and frozen at $-30^{\circ} \mathrm{C}$ until tested. Inoculation was into 3 types of cultured cells: Madin-Darby Canine Kidney cells, human embryonic lung cell-like fibroblasts, and amniotic cell-like epithelium. Cells were examined daily for cytopathic effects and were passaged 3 times at 7-day intervals. Enteroviral infections were typed using antiserum pools and final identification was accomplished by neutralization tests using standard sera for each type. The presence of herpes simplex virus was confirmed and typing was conducted with fluorescein-labeled virus-specific monoclonal antibodies (Micro Track Herpes, Syva, California). Growth of influenza virus was detected by hemadsorption hemagglutination, using supernatants of cell cultures. Typing was performed by hemagglutination-inhibition assay (HAI).

Serology

Serologic evidence of infection with specific pathogens was defined as a 4-fold rise in HAI or complement fixation. All sera were analyzed at a commercial laboratory (SRL, Tokyo, Japan) for rise in titers to RSV, adenovirus, and Mycoplasma pneumoniae by complement fixation; to parainfluenza viruses, 1, 2, and 3 by HAI; and to influenza A and B viruses by both assays. The remaining serum was frozen at $-80^{\circ} \mathrm{C}$ until assayed for enteroviral antibody titers. The presence of antibodies to enteroviruses (coxsackie A9, B2, B5) was determined by the neutralization antibody test. Viruses isolated in cell cultures were used as antigens.

The number of viruses isolated in the nursing home was also compared with that in the community. For this purpose, virus surveillance by fixed point observation in Nagoya City was conducted at 5 major hospitals (Nagoya City Higashi, Nagoya City Midori, Nagoya City Jyouhoku, Nagoya City University, and Chukyou). Rates of influenza were compared with the results of virus surveillance for influenza-like disease in Nagoya City. At that time, cases of influenza in the entire nursing home population (300 elderly residents) underwent similar virus surveillance.

\section{Data Analysis}

The significance of differences between RSV infection and influenza B data was determined the Fischer's exact test. A level of $p<0.05$ was considered statistically significant. Data reported are numbers of cases.

\section{Results}

Two of the 40 participants did not complete the study: one rejected further examination, and the other died of acute myocardial infarction.

Cultures and serology

Two hundred thirty-one specimens for viral culture were obtained and viruses were isolated from 30. These were enteroviral strains in 26 (6 strains of coxackie A9, 7 of coxsackie B2, 3 of coxsackie 
B5, and 10 not determined), herpes simplex I in 2 and influenza B in 2. Influenza B viruses were isolated from elderly participants with ARTI. However, enteroviruses and herpes simplex I viruses were isolated from asymptomatic individuals.

Serum neutralization antibody titers to coxsackie virus were measured using isolated viruses as antigens (Table 1). Neutralization antibody titers before isolation ranged from 1:4 to 1:16. None of the 11 residents with pre- and post-isolation titers exhibited a significant 4 -fold rise in antibody to coxsackie virus.

Staff surveillance detected 25 episodes of ARTI in 23 symptomatic elderly participants during the study period (Figure 1). All 25 cases were evaluated by serologic analysis. Five (20\%) participants showed a 4-fold or greater rise in RSV antibody titers, and 9 (36\%), including 2 from whom influenza $\mathrm{B}$ viruses were isolated at regular investigation, demonstrated significant increases in influenza $\mathrm{B}$ antibody titers. However, 11 participants showed no significant increases in any antibodies.

Virulence

Patients with influenza B virus and RSV infections diagnosed by serology did have clinical symptoms (Table 2). Patients with these 2 viral infections were similar in age. The most common complaint associated with influenza B was coughing in $7 / 9(78 \%$ ), followed by a sore throat in $3 / 9$ $(33 \%)$, rhinorrhea in $2 / 9(22 \%)$, and wheezing in $2 / 9$ (22\%). Similarly, coughing was the most common symptom associated with RSV infection, being present in all cases, followed by a sore throat in $3 / 5$

Table 1 Serological findings for 11 elderly per-

sons with coxsackie virus infections

\begin{tabular}{cccc}
\hline \multirow{2}{*}{ Case number } & Virus & \multicolumn{2}{c}{ Neutralization antibody titers } \\
\cline { 3 - 4 } & & Before & After \\
\hline 1 & CA9 & 8 & 16 \\
2 & CA9 & 16 & 16 \\
3 & CA9 & 8 & 16 \\
4 & CB2 & 4 & 8 \\
5 & CB2 & 8 & 16 \\
6 & CB2 & 8 & 8 \\
7 & CB2 & 8 & 16 \\
8 & CB2 & 16 & 16 \\
9 & CB5 & 8 & 8 \\
10 & CB5 & 8 & 8 \\
11 & CB5 & 16 & 16 \\
\hline
\end{tabular}

Fig. 1 Occurrence of ARTI among elderly participants in the nursing home during the 12-month study period.

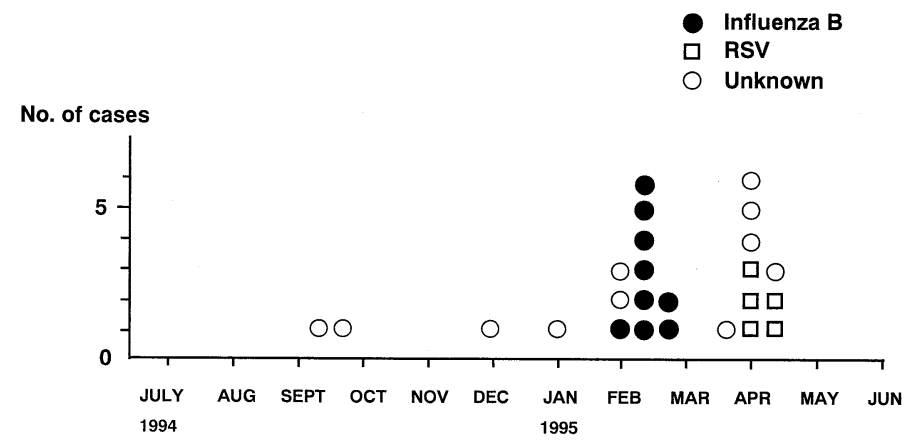


Table 2 Characteristics of patients with influenza

$\mathrm{B}$ and RSV infections

\begin{tabular}{lcc}
\hline & $\begin{array}{c}\text { Influenza B } \\
(\mathrm{n}=9)\end{array}$ & $\begin{array}{c}\text { RSV } \\
(\mathrm{n}=5)\end{array}$ \\
\hline Age(mean $\pm \mathrm{SD})$ & $81.4 \pm 6.9$ & $84.4 \pm 7.3$ \\
Symptoms & & \\
$\quad$ Coughing & $7(78)$ & $5(100)$ \\
Sore throat & $3(33)$ & $3(60)$ \\
Rhinorrhea & $2(22)$ & $1(20)$ \\
Wheezing & $2(22)$ & 0 \\
Sputum production & $1(11)$ & 0 \\
Temperature $\geq 38^{\circ} \mathrm{C}$ & $6(67)$ & $2(40)$ \\
\hline Data are numbers of patients $(\%)$. & No comparisons \\
showed significant differences.
\end{tabular}

(60\%), and rhinorrhea in $1 / 5(20 \%)$. There were no significant differences between the 2 groups in the frequency of temperature elevation to $38^{\circ} \mathrm{C}$ or higher. Overall, the illnesses caused by RSV infection did not differ significantly from those caused by influenza B virus. None required hospitalization and all patients recovered without sequelae.

\section{Epidemiology}

Enteroviruses were identified in asymptomatic nursing home residents between July and December 1994 (Figure 2a). Virus surveillance by fixed-point observation in Nagoya City, performed at 5 hospitals, revealed similar enteroviruses isolated between June and November 1994, most of them being of coxsackie type B2 found again after an interval of 10 years (data not shown). The outbreak of coxsackie B2 in the community was thus 1 or 2 months earlier than that in our nursing home.

Outbreaks of influenza-like disease in the community occurred between November 1994 and February 1995 (Figure 2b). That between December 1994 and January 1995 involved influenza A, and that between February and March 1995 was due to influenza B (data not shown). Cases of influenza B in elderly participants only occurred in February 1995. However, influenza was noted in the nursing home residents in general between January and March 1995, with that in January 1995 being due to influenza A, and that between February and March 1995 caused by influenza B.

\section{Discussion}

Viruses are a major cause of ARTI in all generations, and some of them can cause serious illness and even death in the elderly ${ }^{7,8)}$. In Japan, "Kaze" is the general term for acute respiratory symptoms, and has little etiological meaning ${ }^{9}$. Since most ARTIs have been commonly regarded as belonging within the "Kaze" disease concept, ARTI has been made light of, especially in the elderly. With regard to prevention of influenza, a vaccination program has been promoted in the United States and Europe, especially in high-risk individuals such as the elderly ${ }^{10)}$. But in Japan, vaccine coverage rates of the elderly are now less than $0.1 \%$, because of disinterest in viral infection in this group. A reappraisal of this question may be warranted in light of our findings that certain pathogens such as enterovirus, herpes-simplex virus, RSV and influenza virus infiltrate into nursing homes, and that RSV and influenza virus can cause clinical illness in elderly subjects.

In the present study, the encountered viruses with the most virulence were influenza B virus and RSV. Although RSV was once considered primarily a pathogen of infants and young children, it is increasingly recognized as a cause of serious lower respiratory tract infection in immunocompromised adults and the institutionalized elderly ${ }^{4,5}$. In the present study and elsewhere, comparisons of the 
Fig. 2 Comparisons of viral infection cases between the nursing home and the community: a) enteroviruses, b) influenza.

a) enteroviruses

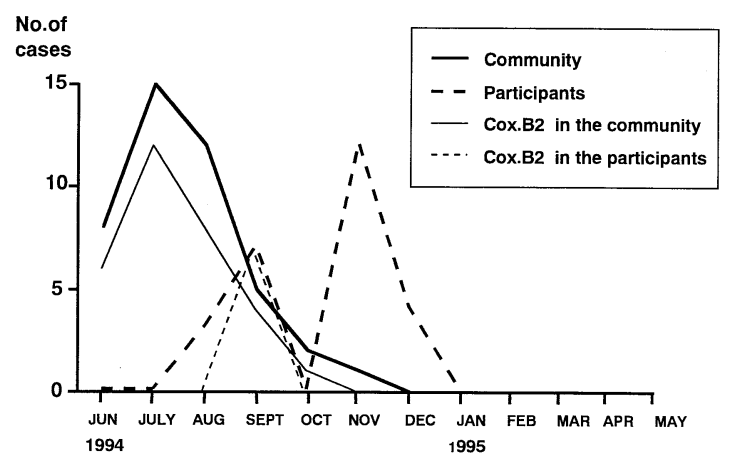

b) influenza

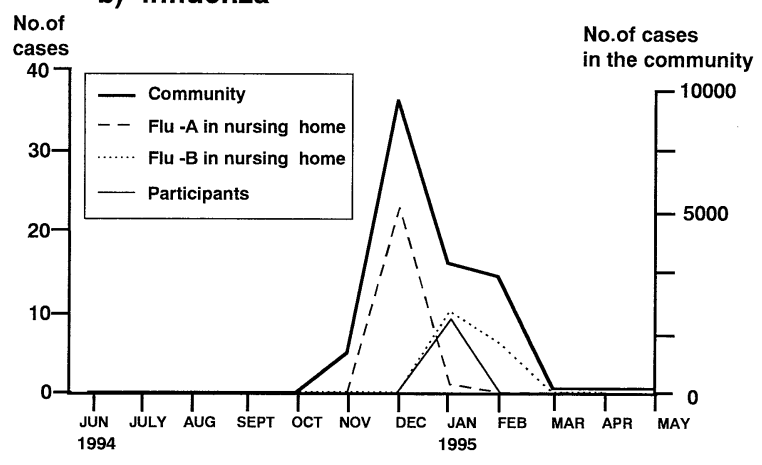

clinical features of patients infected with RSV and influenza revealed little differences in the frequencies of constitutional signs and symptoms ${ }^{5,11,12)}$. This suggests that many influenza-like illnesses in the elderly may actually be caused by RSV.

Enteroviruses usually give rise to subclinical or only mild illness, although they occasionally result in nosocomial outbreaks of meningitis, systematic collapse and death in neonates. In our study, they constituted the most common types of virus isolated from asymptomatic elderly residents. This may reflect preexisting antibody to enteroviruses. The neutralizing antibody response to isolated coxsackie viruses was measured in 11 elderly residents with enteroviral infection, and they had antibody titers $\geqq 1: 4$ before isolation. Since antibody protects from illness but not necessarily infection, these data suggest that humoral immunity to enteroviruses in the elderly remains intact and protective. In no case did the antibody titer to enterovirus show a significant 4 -fold rise. Several previous studies have shown that the antibody response to vaccines is significantly depressed in elderly people as compared to the case with younger people ${ }^{13) \sim 15)}$. It may be that there is a natural decrease with age, although there are reports of little difference between elderly and younger people in antibody response to influenza vaccine ${ }^{16,17}$. Another explanation of our result is that there is a limit to the neutralizing antibody approach. If antibodies had been measured by ELISA, it is possible that a rise would have been detected.

In our nursing home, enteroviruses were mainly isolated in summer and fall, and outbreaks occurred 1 or 2 months after their general appearance in Nagoya City. It is noteworthy that 
coxsackie B2 viruses, isolated after an interval of 10 years, were most prevalent in the institutionalized elderly in the early fall. The clustering suggests that enteroviruses are very efficiently transmitted from the community to the facility. No enteroviruses were isolated in the nursing home in October, and after that they were isolated once again, without any outbreak in Nagoya City (Figure 2a). Possibly, enteroviruses have remained undetected in other residents of our facility. Although only influenza B viruses were isolated in our present elderly participants while influenza A and B occurred in the community during the study period, examination of the entire nursing home population revealed both types of virus. These data suggest that respiratory viruses are transmitted from the community to nursing home residents.

In summary, the present results revealed that respiratory viral infections are a common occurrence in a nursing home, and that RSV and influenza virus exhibit similar virulence for the elderly. This study also suggests that respiratory viruses are readily transmitted from the general community to nursing home residents.

\section{Acknowledgements}

We thank Professor Makoto Itoh, Nagoya City University Medical School, for his welcome advice.

\section{References}

1) Monto AS, Ullman BM: Acute respiratory illness in an American community: The Tecumseh study. JAMA 1974; 227: 164-169.

2) Lui KJ, Kendal AP: Impact of influenza epidemics on mortality in the United States from October 1972 to May 1985. Am J Public Health 1987; 66: 712-716.

3) Goodman RA, Orenstein WA, Munro TF, Smith SC, Sikes RK: Impact of influenza A in a nursing home. JAMA 1982; 247: 1451-1453.

4) Sorvillo FJ, Huie SF, Strassburg MA, Butsumyo A, Shandera WX, Fannin SL: An outbreak of respiratory syncytial virus pneumonia in a nursing home for the elderly. J Infect 1984; 8: 252-256.

5) Osterweil D, Norman D: An outbreak of influenza-like illness in a nursing home. J Am geriatr Soc 1990; 38: 659-662.

6) Barker WH, Mullooly JP: Impact of epidemic type A influenza in a defined adult population. Am J Epidemiol 1980; 112: 798-811.

7) Falsey AR, Treanor JJ, Betts RF, Walsh EE: Viral respiratory infections in the institutionalized elderly: Clinical and epidemiologic findings. J Am Geriatr Soc 1990; 38: 659-662.

8) Falsey AR, Macann RM, Hall WJ et al:: Acute respiratory tract infection in daycare centers for older persons. J Am Geriatr Soc 1995; 43: 30-36.

9) Hirota Y, Kaji M: Scepticism about influenza vaccine efficacy in Japan. Lancet 1994; 344: 408-409.

10) Sugaya N, Nerome K, Ishida M, Mastumoto M, Mitamura K, Nirasawa M: Efficacy of inactivated vaccine in preventing antigenically drifted influenza type A and well-matched type B. JAMA 1994; 272: 1122-1226.

11) Fleming DM, Cross KW: Respiratory syncytial virus or influenza? Lancet 1993; 342: 1507-1510.

12) Falsey AR, Cunningham CK, Barker WH, et al:: Respiratory syncytical virus and influenza A infections in the hospitalized elderly. J Infect Dis 1995; 172: 389-394.

13) Roghmann KJ, Tabloski PA, Bentley DW, Schiffman G: Immune response of elderly adults to pneumococcus: Variation by age, sex, and functional impairment. J Gerontol 1987; 42: 265-270.

14) Fattal-German M, Taillandier J, Mathieu D, Bizzini B: Pneumococcal vaccination of elderly individuals. Vaccine 1991; 9: 542-544.

15) Lesourd B, Wang A, Devillechabrolle A, Moulias R: Influenza vaccination in the elderly. Advances in the Biosciences 1988; 68: 309-316.

16) Sankilampi U, Honkanen PO, Bloigu A, Herva E, Leinonen M: Antibody response to pneumococcal capsular polysaccharide vaccine in the elderly. J Infect Dis 1996; 173: 387-393.

17) Glathe H, Bigl S, Groshe A: Comparison of humoral immune responses to trivalent influenza split vaccine in young, middle-aged and elderly people. Vaccine 1993; 11: 702-705. 
老人ホームにおける高齢者ウイルス感染の検討

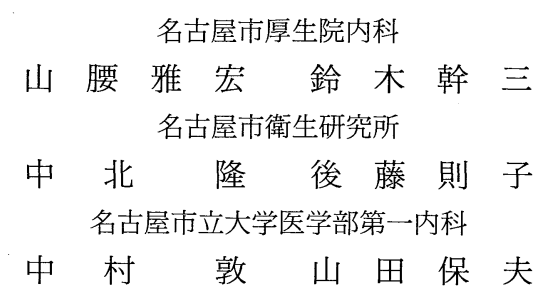

要

この研究の目的は, どのようなウイルスが老人 ホーム内に浸潤し，そのウイルスによって高齢者 がどのような臨床症状を示すのかを調査すること であり，また老人ホーム内でのウイルスの流行と 市中での流行を比較することであった．1994年 7 月から 1995 年 6 月までの 1 年間で, 特別養護老人 ホームに入所中の 40 名の高齢者について, 臨床症 状, 血清ウイルス抗体価, およびウイルス培養に
より検討を行った．エンテロウイルスおよびヘル ペス 1 型ウイルスは症状のない高齢者から分離さ れ, 病原性を示さなかった. 一方血清学的に診断 されたインフルエンザ B および RSV 感染者は, 臨床症状を示した。インフルエンザとエンテロウ イルスの老人ホーム内での流行は, 市中の流行と 関係していた. 呼吸器ウイルスは市中から老人 ホームの入所者へ持ち込まれていることが示唆さ れた。 